\title{
Serum concentrations of tumour necrosis factor $\alpha$ in childhood chronic inflammatory bowel disease
}

\author{
S H Murch, V A Lamkin, M O Savage, J A Walker-Smith, T T MacDonald
}

\begin{abstract}
Serum tumour necrosis factor $\alpha$ (TNF $\alpha$ ) concentrations were measured by enzyme linked immunoadsorbent assay in $\mathbf{3 1}$ normal children and during 65 episodes of clinical remission and 54 episodes of relapse in 92 children with chronic inflammatory bowel disease. An appreciable rise in TNF $\alpha$ was found only in children in relapse of ulcerative colitis and colonic Crohn's disease. The group of children with small bowel Crohn's disease in relapse did not show increases of TNF $\alpha$ above control concentrations, despite an equivalent rise in disease indices. Height velocity was depressed in children with relapse of large bowel Crohn's disease and ulcerative colitis compared with the equivalent condition in remission. The impairment of growth velocity was significantly greater in relapse of large bowel Crohn's disease and ulcerative colitis than in small bowel Crohn's disease alone, although for the subgroups in stage 1 puberty (prepubertal) the differences were not significant. Inadequate growth in chronic inflammatory bowel disease is currently ascribed to inadequate nutrition and TNF $\alpha$ may contribute to this through its cachexia inducing effects. It may, in addition, diminish pituitary growth hormone release. These results suggest that production of TNF $\alpha$ may be associated with growth failure in relapse of colonic inflammatory bowel disease.
\end{abstract}

Tumour necrosis factor $\alpha(\mathrm{TNF} \alpha) /$ cachectin, a cytokine produced mainly by activated macrophages and monocytes, is generating increasing interest both as a mediator of tissue maturation and local immunity and as a destructive agent

Accepted for publication 10 September 1990 capable of causing profound cachexia and tissue injury. The balance of beneficial and deleterious effects are determined by its level of production and its interaction with other mediators. ${ }^{1-4}$

Excess production of TNF $\alpha$ has been found in parasitic diseases including trypanosomiasis and malaria ${ }^{5}$ in which it may be a major mediator of cerebral involvement ${ }^{6}$ ), in malignancy, ${ }^{7}$ connective tissue diseases, ${ }^{8}$ and septicaemia. ${ }^{9}$ High serum concentrations have been shown to be associated with poor outcome in meningococcal septicaemia ${ }^{10}$ and raised concentrations in cerebrospinal fluid have been shown in bacterial meningitis in childhood. ${ }^{\prime \prime}$

There have been no studies in which TNF $\alpha$ concentrations have been measured in childhood chronic inflammatory conditions, and it has not previously been implicated in growth failure.

\section{Methods}

\section{PATIENTS}

\section{Control subjects}

Twenty five of the 31 children used as control subjects underwent colonoscopy and barium followthrough examination for investigation of possible inflammatory bowel disease. In all cases full investigation was normal and a diagnosis of functional abdominal pain or irritable bowel syndrome was made. Biopsy specimens showed no evidence of microscopic colitis, barium followthrough was normal or showed lymphoid nodular hyperplasia only (five cases) and there was no rise in erythrocyte sedimentation rate or $\mathrm{C}$ reactive protein. In the other children venesection was performed to investigate short stature (two cases), possible food allergy (one case), and asthma (three cases). All children were undergoing venesection for other investigations.

\section{Chronic inflammatory bowel disease}

All patients had been assigned a definite diagnosis of Crohn's disease or ulcerative colitis on the basis of radiological and histological findings and had undergone colonoscopy and barium followthrough investigation in the preceding 12 months. The children with Crohn's disease were divided into two groups on the basis of colonic involvement. Those with disease affecting the small bowel up to and including the terminal ileum, but with no evidence of macroscopic or microscopic involvement of the caecum or colon, were labelled as having small bowel Crohn's disease. Those whose disease included the caecum or colon, whether or not there was also small bowel involvement, were included in the large bowel Crohn's disease group. 
Serum $T N F \alpha(p g / m l)$ in control subjects and in disease groups.

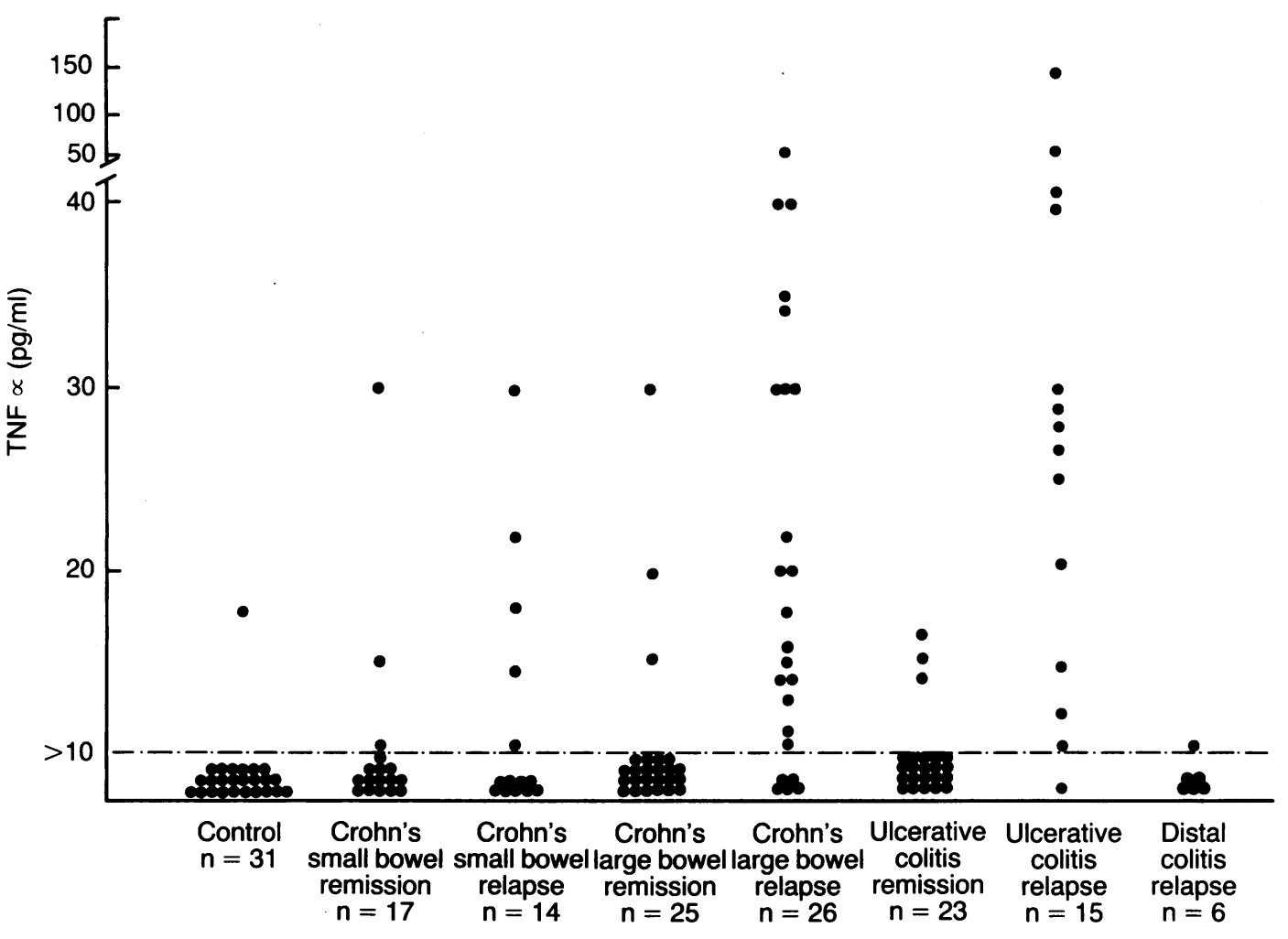

DISEASE ACTIVITY

Patients were assessed in the paediatric inflammatory bowel disease clinic at two month intervals if well and every two to four weeks if not. Disease activity was assessed on the basis of reported symptoms, change in weight, clinical examination, and investigation, with the patient classified as follows. (a) Fully in remission (asymptomatic, appropriate weight gain, no abdominal tenderness or masses, no active perianal or oral disease, no appreciable rise in disease indices at last review). (b) Partially relapsed (minor episodic abdominal pain without systemic upset; active perianal disease; poor weight gain; isolated rise in disease indices at last review). (c) Relapsed (recurrent moderate or severe abdominal pain or diarrhoea $>5$ times daily with stools containing blood or mucus, or both; appreciable weight loss; abdominal tenderness or mass). Only those patients who were classified as fully relapsed or fully in remission were included in the study.

ASSESSMENT OF GROWTH AND PUBERTAL STAGE All patients underwent formal auxological measurement and pubertal staging at each clinic visit and during any admission. Standing height was measured by the same observer (VAL) using a stadiometer and height velocity was calculated over the preceding three or six months. A pubertal stage was assigned on the basis of genital development in boys and breast development in girls using standard ratings from stage 1 (prepubertal) to stage 5 (adult). ${ }^{12}$

TNF $\alpha$ ASSAY PROTOCOL

After venesection blood was stored overnight at $4^{\circ} \mathrm{C}$ before being centrifuged at $2000 \mathrm{rpm}$ for 10 minutes and the supernatant separated. The serum was then stored at $-70^{\circ} \mathrm{C}$ until assayed.

Aliquots of $50 \mu \mathrm{l}$ of serum were assayed for TNF $\alpha$ by the enzyme linked immunoadsorbent assay (ELISA) technique, using a commercially available assay ( $T$ Cell Sciences, Cambridge MA, USA). Results were expressed in $\mathrm{pg} / \mathrm{ml}$, with the lower limit of detection of the assay being $10 \mathrm{pg} / \mathrm{ml}$.

\section{STATISTICAL ANALYSIS}

The Kolmogorov-Smirnov 2 group test was used for comparison of $\mathrm{TNF} \alpha$ and pubertal stages between groups and the unpaired Student's $t$ test for analysis of erythrocyte sedimentation rate, $C$ reactive protein, and height velocity.

\section{Results}

TNF $\alpha$ CONCENTRATION AND DISEASE ACTIVITY Serum TNF $\alpha$ was significantly raised above control values ( 30 out of 31 below $10 \mathrm{pg} / \mathrm{ml}$, range $<10-18$ ) in only two disease states, both associated with colonic inflammation (Figure and Table I): ulcerative colitis in relapse $(n=11$, median $27 \mathrm{pg} / \mathrm{ml}$, range $<10-150, \mathrm{p}<0.000007)$ and Crohn's colitis in relapse $(n=25$, median 16 $\mathrm{pg} / \mathrm{ml}$, range $<10-60, \mathrm{p}<0.000002)$. Relapse of small bowel Crohn's disease alone, with no evidence of colonic involvement, was not associated with a significant rise in $\mathrm{TNF} \alpha$ above control values $(\mathrm{n}=13$, median $<10 \mathrm{pg} / \mathrm{ml}$, range $<10-30, \mathrm{p}>0 \cdot 2$ ), despite insignificant differences between the small and large bowel groups in the severity of relapse as measured by disease indices (see Table I: mean (SEM) erythrocyte sedimentation rate $27 \cdot 38(4 \cdot 65) v 23 \cdot 2(2 \cdot 72) \mathrm{mm}$ in 1st hour, mean (SEM) C reactive protein $40 \cdot 1$ 
TABLE II Current age and mean (SEM) growth velocity in entire group and in patients in stage 1 puberty in relapse and remission groups

\begin{tabular}{|c|c|c|c|c|}
\hline \multirow[b]{2}{*}{ Condition } & \multirow[b]{2}{*}{$\begin{array}{l}\text { Age } \\
\text { (years) }\end{array}$} & \multicolumn{2}{|c|}{ Growth velocity } & \multirow[b]{2}{*}{$p^{\star}$} \\
\hline & & $\begin{array}{l}\text { Entire } \\
\text { group } \\
\text { (cm/year) }\end{array}$ & $\begin{array}{l}\text { Patients in stage } 1 \\
\text { puberty }(\mathrm{cm} / \text { year })\end{array}$ & \\
\hline Control subjects & $\begin{array}{l}11 \cdot 35 \\
(0 \cdot 51)\end{array}$ & \multirow{8}{*}{$\begin{array}{l}6 \cdot 49 \\
(0 \cdot 78) \\
5 \cdot 24 \\
(0 \cdot 89) \\
4 \cdot 90 \\
(0 \cdot 55) \\
2 \cdot 35 \\
(0.47) \\
5 \cdot 59 \\
(0 \cdot 48) \\
2 \cdot 14 \\
(0.62) \\
5 \cdot 64 \\
(0.74)\end{array}$} & \multirow{8}{*}{$\begin{array}{l}6 \cdot 48 \\
(0 \cdot 89, \mathrm{n}=4) \\
3 \cdot 78 \\
(0 \cdot 83, \mathrm{n}=5) \\
4 \cdot 71 \\
(0 \cdot 69, \mathrm{n}=9) \\
2 \cdot 58 \\
(0 \cdot 71, \mathrm{n}=11) \\
5 \cdot 30 \\
(0 \cdot 18, \mathrm{n}=10) \\
2 \cdot 50 \\
(0 \cdot 98, \mathrm{n}=9)\end{array}$} & \\
\hline Small bowel Crohn's disease in remission & $\begin{array}{l}13.74 \\
(0.61)\end{array}$ & & & NS \\
\hline Small bowel Crohn's disease in relapse & $\begin{array}{l}14 \cdot 48 \\
(0 \cdot 49)\end{array}$ & & & \\
\hline Colonic Crohn's disease in remission & $\begin{array}{l}13.34 \\
(0.57)\end{array}$ & & & NS \\
\hline Colonic Crohn's disease in relapse & $\begin{array}{l}13 \cdot 20 \\
(0 \cdot 34)\end{array}$ & & & $<0.001$ \\
\hline Ulcerative colitis in remission & $\begin{array}{l}12 \cdot 66 \\
(0 \cdot 74)\end{array}$ & & & NS \\
\hline Ulcerative colitis in relapse & $\begin{array}{l}11.58 \\
(0.99)\end{array}$ & & & $<0.001$ \\
\hline Distal colitis in relapse & $\begin{array}{l}12 \cdot 4 \\
(1 \cdot 06)\end{array}$ & & & NS \\
\hline
\end{tabular}

`Probability values, by unpaired Student's $t$ test, comparing group mean height velocity (entire group) with that in subgroup with relapsed small bowel Crohn's disease. NS=not significant.

(6.9) $v 37 \cdot 7(4 \cdot 49) \mathrm{mg} / \mathrm{l}, \mathrm{p}>0 \cdot 2)$. In the small group with distal colitis alone serum TNF $\alpha$ was not raised above control values despite a greater rise in the sedimentation rate than in the group with relapsed colonic Crohn's disease $(39 \cdot 3$ $(14 \cdot 1) v 23 \cdot 2(2 \cdot 72), \mathrm{p}<0 \cdot 05)$ and a similar rise in $\mathrm{C}$ reactive protein. Ulcerative colitis in relapse was associated with a higher sedimentation rate than relapsed colonic Crohn's disease $(36 \cdot 2(4 \cdot 7)$ $v 23.2(2 \cdot 72), \mathrm{p}<0.007)$ with no significant difference in concentrations of $\mathrm{C}$ reactive protein or TNF $\alpha$.

\section{TNF $\alpha$ CONCENTRATION AND CURRENT HEIGHT VELOCITY}

Current mean growth velocity was significantly lower in the groups with relapse of colonic Crohn's disease $(p<0.001)$ and ulcerative colitis $(p<0.001)$ than in the groups with the equivalent condition in remission (Table II). Although for the groups with small bowel Crohn's disease there was no significant difference between those in relapse and remission, analysis of the subgroups in stage 1 puberty showed significantly lower growth in those with symptomatic relapse $(\mathrm{p}<0.05)$.

Current growth velocity was significantly greater in the group with relapsed small bowel Crohn's disease than in those with relapsed Crohn's colitis $(p<0.0002)$ or ulcerative colitis $(\mathrm{p}<0.0005)$.

No significant differences were found between the groups in overall pubertal staging, although patients in the group with small bowel Crohn's disease in relapse were significantly older (mean (SEM) age $14.48(0.49)$ years) than those with colonic Crohn's disease $(13 \cdot 20(0 \cdot 34)$ years $)$ or ulcerative colitis $(11.58(0.99)$ years $)$ in relapse $(p<0.05)$. Further analysis of the subgroups in stage 1 puberty, however, showed no significant differences between the groups, although the number of cases was small. The group with distal colitis had less impairment of growth than the groups with relapsed colonic Crohn's disease $(p<0.02)$ or ulcerative colitis $(p<0.0004)$.

Fifteen of the 48 patients with colonic disease in remission were taking prednisolone $(5-30 \mathrm{mg}$ ) daily compared with 27 of the 46 with colonic disease in relapse $(7 \cdot 5-40 \mathrm{mg})$, two of the 17 with small bowel disease in remission $(5-30 \mathrm{mg}$ ), and three of the 13 with small bowel disease in relapse (5-20 mg). No significant differences in serum TNF $\alpha$ or height velocity were found between those taking prednisolone and those not taking corticosteroid treatment.

\section{Discussion}

These results show a clear difference between the concentrations of serum TNF $\alpha$ in children with relapsed colonic inflammatory bowel disease and those with relapsed Crohn's disease affecting the small bowel alone. The TNF $\alpha$ in serum is probably an overspill from that produced locally by activated macrophages in the colon and is therefore presumably an underestimate of local production. In support of this, a similar variation between local and systemic TNF $\alpha$ concentration has been shown by Nadal et al, ${ }^{11}$ who found concentrations in the cerebrospinal fluid of $57-20000 \mathrm{pg} / \mathrm{ml}$ in 11 children with bacterial meningitis, with serum TNF $\alpha$ detectable in only one.

Most TNF $\alpha$ is produced in activated macrophages and monocytes, although it is produced to some extent by hepatic Kupffer cells, cerebral astrocytes, and microglial cells. ${ }^{1-4}$ Activated macrophages and T cells are abundant in intestinal mucosa in inflammatory bowel disease ${ }^{13}$ and in recent experiments it has been shown that production of TNF $\alpha$ is increased at the single cell level, ${ }^{14}$ thus showing formally that at least some of the TNF $\alpha$ detected in serum in inflammatory bowel disease is gut derived.

Populations of histiocytes and macrophages with different morphology and biochemical activity have been found in the small bowel compared with the colon. ${ }^{15}$ It is thought that this difference reflects the requirement for antigen handling in the small intestine as opposed to scavenging in the bacteria laden colon. In colonic inflammatory bowel disease a further distinct group of macrophages has been found to replace those normally present in the colon, the population returning to normal with treatment. ${ }^{15}$ Variation in expression of surface markers on $\mathrm{T}$ cells and macrophages between colonic and small bowel inflammatory bowel disease has more recently been shown. ${ }^{16}$ These results suggest that our findings of increased serum TNF $\alpha$ in relapsed colonic but not small bowel disease may reflect fundamental differences between the populations of macrophages in these sites.

TNF $\alpha$ has been shown in animals to have a cytopathic effect on bowel mucosa, ${ }^{17}$ probably mediated in part by platelet activating factor, ${ }^{18}$ raising the possibility that it may be involved in the pathogenesis of inflammatory bowel disease. Multifocal gastrointestinal infarction, mediated by enhanced procoagulant activity, has in fact recently been proposed as a pathogenetic mechanism in Crohn's disease, ${ }^{19}$ and raised concentrations of interleukin-1 have been reported..$^{202}$ Production of TNF $\alpha$ from activated macrophages, and its subsequent systemic action, has been attenuated by administration of non-steroidal anti-inflammatory drugs or 
corticosteroids, ${ }^{422}$ although we found no significant difference in serum TNF $\alpha$ between patients taking mesalazine, sulphasalazine, or prednisolone and those taking no drugs.

Suppression of linear growth is a common feature of childhood chronic inflammatory bowel disease, affecting up to $30 \%$ of patients. ${ }^{23-27}$ Although children may present with growth failure alone, without symptoms or weight loss, ${ }^{28}$ it is currently accepted that nutritional deficiency is the major cause of the growth failure and that caloric supplementation can restore growth. ${ }^{23}$ 25-27 29-32 Somatomedin C (insulin like growth factor 1) concentrations have been found to be low in growth impaired children with childhood inflammatory bowel disease and to increase as calorie intake improves. ${ }^{33}$ Delayed gastric emptying, which may contribute to poor oral intake, has also been found in malnourished children with Crohn's disease. ${ }^{34}$

Although there seems to be major variations between the reported studies in the amount of caloric supplementation required to reinstitute growth and the nutritional supplementation was provided in several of the studies by methods which may in themselves be therapeutic, ${ }^{35-37}$ such as parenteral nutrition ${ }^{23}{ }^{3132}$ or elemental diet, ${ }^{27}$ it is clear that restoring caloric intake, even using a polymeric non-elemental $\operatorname{diet}^{29}$ or by aggressive oral nutrition ${ }^{25}$ may lead to improvement of linear growth velocity in many patients.

The possible contribution of growth hormone deficiency to the growth suppression of chronic inflammatory bowel disease has been more controversial. After the report by McCaffery $e a^{2{ }^{26}}$ of impaired growth hormone response to insulin induced hypoglycaemia in 11 of 14 growth retarded patients, subsequent studies have failed to show consistent abnormalities of growth hormone production..$^{38-40}$ These studies may be criticised on the grounds that growth hormone reserve was not retested in remission and that growth hormone concentrations in the normal range were considered appropriate, although raised plasma concentrations are normally found in protein-calorie malnutrition. ${ }^{41}$ In the one report in which growth hormone reserve was retested it was found to be low in relapse and normal in remission. ${ }^{42}$

The value of surgical resection in stimulating growth, particularly in children in early puberty, has been emphasised by recent reports. ${ }^{43-45}$ Such pronounced improvement of growth velocity, after resection of affected bowel, suggests that one or more mediators may be produced locally which have an inhibitory effect upon growth.

Although it is not possible to infer such direct inhibition from these results, TNF $\alpha$ could potentially affect growth by its adverse effects on appetite, nutrition, and growth hormone production. Its effects on nutrition are profound, with chronic production causing wasting despite unlimited intake. ${ }^{46}$ In vitro studies have shown catabolic changes at the cellular level. ${ }^{7+8}$ Administration of recombinant $T N F \alpha$ to animals and humans causes delayed gastric emptying, ${ }^{49}$ profound anorexia, weight loss, and a redistribution of body proteins with depletion of skeletal muscle protein and increase in hepatic acute phase protein synthesis. ${ }^{5051}$ Hepatic expression of albumin mRNA was decreased by $90 \%$ after TNF $\alpha$ administration to mice..$^{52}$ In addition, $\mathrm{TNF} \alpha$ has been shown in vitro to affect anterior pituitary hormone release, ${ }^{53}$ specifically diminishing release of growth hormone. ${ }^{54}$

Many of the children in this study were passing through puberty, or alternatively suffering pubertal delay because of their disease. The most unusual finding was the relatively good growth of the group with relapsed small bowel Crohn's disease, and it seems likely that more members of this group were undergoing their pubertal growth spurt, despite the similarities in overall pubertal staging between the groups. The mean age of this group was significantly greater than the others and only this subgroup in stage 1 puberty had a lower mean height velocity than that of the entire group. Further study of growth and TNF $\alpha$ production in prepubertal children with chronic inflammatory bowel disease is required.

With the potential advent of therapeutic monoclonal anti-TNF $\alpha$ antibodies in conditions where TNF $\alpha$ may be playing a pathological part, it is clear that further work is required to determine the site of $\mathrm{TNF} \alpha$ production in chronic inflammatory bowel disease and to establish whether its excess production does play a part in mucosal inflammation. In our study the highest serum TNF $\alpha(150 \mathrm{pg} / \mathrm{ml})$ was found in a girl in whom toxic dilatation of the colon was considered possible (she settled on conservative management) and it will be important to study $\mathrm{TNF} \alpha$ production in cases where this diagnosis is certain. Should TNF $\alpha$ be found to have a role in the pathogenesis of this life threatening complication (and its credentials for direct bowel wall destruction are well established from animal work), ${ }^{1718}$ then therapeutic monoclonal antiTNF $\alpha$ antibodies may present an important alternative to the radical surgery currently required. Their possible future use in less serious relapse of disease will be more difficult to assess, and it is important that those looking after children with chronic inflammatory bowel disease should aim for precise localisation of the affected bowel and stringent monitoring of growth.

This work was supported by the Crohn's in Childhood Research Association and the Wellcome Trust.

1 Tracey KJ, Lowry SF, Cerami A. Cachectin, a hormone that triggers acute shock and chronic cachexia. I Infect Dis 1988 157: 413-20.

2 Beutler B. The presence of cachectin/tumor necrosis factor in human disease states. Am $\mathcal{f}$ Med 1988; 85: 278-80.

3 Ziegler EJ. Tumor necrosis factor in humans. $N$ Engl $\mathcal{F}$ Med 1988; 318: $1533-5$

Tracey KJ, Vlassara H, Cerami A. Cachectin/tumour necrosis factor. Lancet 1989 ; i: $1122-6$.

5 Scuderi P, Lam KS, Ryan KJ, et al. Raised serum levels of tumour necrosis factor in parasitic infections. Lancet 1986 i: $1634-5$.

6 Clark IA, Cowden WB, Butcher GA, Hunt NH. Possible roles of tumor necrosis factor in the pathology of malaria. $A m \mathcal{J}$ Pathol 1987; 129: 192-9.

7 Balkwill F, Burke F, Talbot D, et al. Evidence for tumour necrosis factor production in cancer. Lancet 1987; ii: 1229 32.

8 Maury CPJ, Teppo AM. Tumor necrosis factor in the serum of patients with systemic lupus erythematosus. Arthritis Rheum 1989; 32: 146-50.

9 Michie HR, Manogue KR, Spriggs DR, et al. Detection of circulating tumor necrosis factor after endotoxin administration. N Engl F Med 1988; 318: 1481-6.

10 Waage A, Halstensen A, Espewick K. Association between tumour necrosis factor in serum and fatal outcome in meningococcal disease. Lancet 1987 ; i: 355-7. 
11 Nadal D, Leppert D, Frei K, et al. Tumour necrosis factor $\alpha$ in infectious meningitis. Arch Dis Child 1989; 64: 1274-9.

12 Tanner JM. Physical growth and development. In: Forfar JO, Arneil GC, eds. Textbook of paediatrics. 3rd ed. Edinburgh: Churchill Livingstone, 1984: 291-8.

13 Mahida YR, Patel S, Wu K, Jewell DP. Interleukin 2 receptor expression by macrophages in inflammatory bowel disease. Clin Exp Immunol 1988; 74: 382-6.

14 MacDonald TT, Hutchings P, Choy M-Y, Murch S, Cooke A. Tumor necrosis factor $\alpha$ and interferon- $\gamma$ production measured at the single cell level in normal and inflamed human intestine. Clin Exp Immunol 1990; 81: 301-5.

15 Selby WS, Poulter LW, Hobbs S, et al. Heterogeneity of HLA-DR-positive histiocytes in human intestinal lamina HLA-DR-positive histiocytes in human intestinal lamina propria: a combined histochemical and

16 Choy MY, Walker-Smith JA, Williams CB, McDonald TT. Differential expression of CD25 (interleukin-2 receptor) on lamina propria $T$ cells and macrophages in the intestinal lesions in Crohn's disease and ulcerative colitis. Gut 1990; 31: 1365-70.

17 Tracey KJ, Wei HE, Manogue KR, et al. Cachectin/tumor necrosis factor induces cachexia, anemia and inflammation. fExp Med 1988; 167: 1211-27.

18 Sun X-M, Hseueh W. Bowel necrosis mediated by tumour necrosis factor is mediated by platelet-activating factor. necrosin Invest $1988 ; 81: 1328-31$.

19 Wakefield AJ, Dhillon AP, Rowles PM, et al. Pathogenesis of Crohn's disease: multifocal gastrointestinal infarction. Lancet 1989; ii: 1057-62.

20 Suzuki Y, Tobin A, Quinn D, Whelan D, O'Morian C. Interleukin-1 in inflammatory bowel disease. Gastro enterology 1989; 96: A498.

21 Satsangi J, Walstencroft JC, Cason J, et al. Interleukin-1 in Crohn's disease. Clin Exp Immunol 1987; 67: 594-605.

22 Evans DA, Jacobs DO, Revhaug A, Wilmore DW. The effects of tumor necrosis factor and their selective inhibition by ibuprofen. Ann Surg 1989; 209: 312-21.

23 Kelts DG, Grand RJ, Shen G, et al. Nutritional basis of growth failure in children and adolescents with Crohn's disease. Gastroenterology 1979; 76: 720-7.

24 Evans CM, Walker-Smith JA. Recording growth and development in children with inflammatory bowel disease. $B M \mathcal{F}$ 1989; 298: 1312-3.

25 Kirschner BS, Klich JR, Kalman SJ, et al. Reversal of growth retardation in Crohn's disease with therapy emphasizing oral retardation in Crohn's disease with therapy emphasizing
nutritional restitution. Gastroenterology 1981; 80: 10-5.

26 McCaffery TD, Nasr K, Lawrence AM, Kirsner JB. Severe growth retardation in children with inflammatory bowel disease. Pediatrics 1970; 45: 386-93.

27 Belli DC, Seidman E, Bouthillier L, et al. Chronic intermittent elemental diet improves growth failure in children with Crohn's disease. Gastroenterology 1988; 94: 603-10.

28 Kanof ME, Lake AM, Bayless TM. Decreased height velocity in children and adolescents before the diagnosis of Crohn's disease. Gastroenterology 1988; 95: 1523-7.

29 Aiges H, Markowitz J, Rosa J, Daum F. Home nocturnal supplemental nasogastric feedings in growth-retarded adolescents with Crohn's disease. Gastroenterology 1989; 97: 905-10.

30 Seidman EG, Roy CC, Weber AM, Morin CL. Nutritional therapy of Crohn's disease in childhood. Dig Dis Sci 1987; 32: 82-8S

31 Armanath RP, Fleming CR, Perrault J. Home parenteral nutrition in chronic intestinal diseases: its effect on growth and development. $\mathcal{F}$ Pediatr Gastroenterol Nutr 1987; 6: 89-95.

32 Layden T, Rosenberg J, Nemchansky B, Elson C, Rosenberg I. Reversal of growth arrest in adolescents with Crohn's disease after parenteral alimentation. Gastroenterology 1976 ; 70: $1017-26$

33 Kirschner BS, Sutton MM. Somatomedin-C levels in growth impaired children and adolescents with chronic inflammatory bowel disease. Gastroenterology 1986; 91: 830-6.

34 Grill BB, Lange R, Markovitz R, et al. Delayed gastric emptying in children with Crohn's disease. $\mathcal{f}$ Clin Gastroenterol 1985; 7: 216-26.

35 Giaffer MH, North G, Holdsworth CD. Controlled trial of polymeric versus elemental diet in treatment of active Crohn's disease. Lancet 1990; 335: 816-9.

36 Seidman EG. Nutritional management of inflammatory bowel disease. Gastroenterol Clin North Am 1989; 18: 129-55.

37 Sanderson IR, Udeen S, Davies PSW, Savage MO, WalkerSmith JA. Remission induced by elemental diet in small Smith JA. Remission induced by elemental diet in sm

38 Gotlin RW, Dubois RS. Nyctohemeral growth hormone levels in children with growth retardation and inflammatory bowe disease. Gut 1973; 14: 191-5.

39 Chong SK, Grossman A, Walker-Smith JA, Rees LH. Endoc rine dysfunction in children with Crohn's disease. $\mathcal{F}$ Pediat Gastroenterol Nutr 1984; 3: 529-34.

40 Farthing MJ, Campbell CA, Walker-Smith J, et al. Nocturnal growth hormone and gonadotrophin secretion in growth

41 Pimstone BL, Barbezat G, Hansen JDL, Murray P. Studies on growth hormone secretion in protein-calorie malnutrition. Am $\mathcal{F}$ Clin Nutr 1968; 21: 482-7.

42 Green JRB, O'Donoghue DP, Edwards CRW, Dawson AM A case of apparent hypopituitarism complicating chronic inflammatory bowel disease in childhood and adolescence. Acta Paediatr Scand 1977; 66: 643-7.

43 Alperstein G, Daum F, Fisher SE, et al. Linear growth following surgery in children and adolescents with Crohn's disease: relationship to pubertal status. F Pediatr Surg 1985; 20: 129-33.

44 McClain BI, Davidson PM, Stokes KB, Beasley SW. Growth after gut resection for Crohn's disease. Arch Dis Child 1990; 65: 760-2.

45 Davis G, Evans CM, Shand WS, Walker-Smith JA. Surgery for Crohn's disease in childhood - influence of site of disease and operative procedure on outcome. Br $₹$ Surg 1990; 77 : $891-4$.

46 Oliff A, Defeo-Jones D, Boyer M, et al. Tumors secreting human TNF/Cachectin induce cachexia in mice. Cell 1987 50: 555-63.

47 Torti FM, Dieckman B, Beutler B, Cerami A, Ringold GM. A macrophage factor inhibits adipocyte gene expression: an in vitro model of cachexia. Science 1985; 229: 867-9.

48 Lee MD, Zentella A, Pekala PH, Cerami A. Effect of endotoxin-induced monokines on glucose metabolism in the muscle cell line L6. Proc Natl Acad Sci USA 1987; 84:

49 Evans RD. Gastric effects of cytokines. Anaesthesia 1989; 44: 518.

50 Michie HR, Sherman ML, Spriggs DR, Rounds J, Christie M, Wilmore DW. Chronic TNF infusion causes anorexia bu not accelerated nitrogen loss. Ann Surg 1989; 209: 19-24.

51 Fong Y, Moldawer LL, Marano M, et al. Cachectin/TNF or IL-1 $\alpha$ induces cachexia with redistribution of body proteins. Am F Physiol 1989; 256: R659-65.

52 Brenner DA, Buck M, Feitelberg SP, Chojkier M. Tumo necrosis factor- $\alpha$ inhibits albumin gene expression in murine model of cachexia. 7 Clin Invest $1990 ; 85: 248-55$.

53 Milenkovic L, Rettori V, Snyder GD, et al. Cachectin alters anterior pituitary hormone release by a direct action in vitro. Proc Natl Acad Sci USA 1989; 86: 2418-22.

54 Walton PE, Cronin MJ. Tumor necrosis factor- $\alpha$ inhibits growth hormone secretion from cultured anterior pituitary cells. Endocrinology 1989; 125: 925-9. 